\title{
Diferentes perspetivas de um ensino conservador: o ensino liceal em Portugal durante o Estado Novo (1936-1960)
}

\section{Different outlooks on a conservative education: education in lyceums in Portugal under the rules of the New State (1936-1960)}

\author{
António Gomes Ferreira ${ }^{1}$ \\ Luís Mota ${ }^{1}$
}

\begin{abstract}
RESUMO
A nossa análise fixou-se sobre o período de afirmação do dispositivo curricular liceal e a consolidação do programa da modernidade em Portugal, entre as décadas de trinta e cinquenta do século passado. Contudo, o Estado Novo ao demarcar-se de preocupações como o prolongamento da escolaridade e as teses da escola única recolocou na ordem do dia o problema da identidade do ensino do liceu. O debate incidiu, particularmente, sobre três eixos, os objetivos do ensino liceal, a organização curricular e a democratização. Centramo-nos na reflexão sobre os objetivos definidos para o ensino liceal e na sua organização curricular. Nesta perscrutamos a controvérsia em torno do regime de classe e do regime de disciplinas. Damos conta da discussão e das sucessivas tomadas de decisão a propósito da duração e estruturação dos ciclos de estudos. Articulado com os objetivos propostos para o ensino liceal, adquiriu alguma relevância a problemática das disciplinas que deveriam integrar, ou não, o plano de estudos bem como a justificação das opções adotadas. Convocamos, para este nosso estudo, como fontes, muito especialmente, a legislação que sustentou as alterações nos planos curricular e disciplinar, os diários da Assembleia Nacional e os pareceres da Câmara Corporativa aí insertos, bem como textos publicados na imprensa de educação e ensino, ainda que cônscios dos efeitos perversos da censura prévia.

Palavras-chave: ensino liceal; ensino secundário; Liceus; Estado Novo; Educação Nacional.
\end{abstract}

1 Universidade de Coimbra. Coimbra, Portugal. R. Da Ilha - Palácio dos Grilos. 3000-214. 


\begin{abstract}
Our analysis focused on the establishment of the curricula of lyceums and the consolidation of the programme for modernity in Portugal, from the nineteen thirties to the fifties. The New State, however, a conservative and nationalist regime, while losing touch with concerns like extending schooling and the theses of a single secondary education, put back on the agenda the issue of the identity of education performed in lyceums. The discussion was focused, particularly, on three pillars: the goals of education in lyceums, the curricular organization and democratization. Our study was centred on the objectives established for lyceums and the organization of its curricula. Herein, we address the controversy about the class regime and the subject regime. We carried out the discussion and the decisions taken on the duration and structure of the study cycles. Connected to the objectives proposed for lyceums, the topic of the subjects which should or should not be included in the studies plan and the grounds on which such choices were made gained additional importance. As sources for our study we selected in particular the legislation which supported the changes to the curricula and subject plan, the diaries of the National Assembly and the opinions of the Corporativist Chamber addressed in this case, as well as publications by the media specialized in education and teaching, without losing sight of the perverse effects of the censorship.
\end{abstract}

Keywords: education at lyceums; secondary education; Lyceums; New State; National Education.

\title{
Introdução
}

Embora se tenha de reconhecer que as políticas educativas em Portugal apresentam particularidades que singularizam a evolução do sistema educativo do país, também é verdade que, o que acontece em Portugal no âmbito do ensino, ao longo da época contemporânea, não escapa a entendimentos e perspetivas que vêm do centro da Europa. Os estudos sobre os liceus e o ensino liceal, no quadro da historiografia da educação, vêm mostrando que a sua institucionalização em Portugal seguiu a construção do ensino secundário europeu, consolidado nos modelos do liceu francês e do ginásio alemão.

Os liceus portugueses tenderam a seguir uma idêntica estrutura curricular e organizacional que, de resto, se manteria até final dos anos 50 do século passado. Mas isso não significa que se esteja perante uma evolução linear e sem controvérsias. Há um passado, condições sociais e ideológicas que marcam as 
discussões e os percursos das sucessivas reformas. Sem se dever ignorar os antecedentes estudos dos colégios dos jesuítas e os marcados pelas reformas pombalinas, os liceus conheceram, antes da sua consolidação organizacional durante os anos trinta e quarenta do século $\mathrm{XX}$, duas etapas no seu processo evolutivo. A primeira iniciou-se com aquele que é considerado o momento da sua criação, em 1836, pautado pela publicação do Plano dos liceus nacionais, de Passos Manuel (Decreto de 17 de novembro); fase que se prolongou até finais do século XIX e se traduziu pelas dificuldades experimentadas na sua institucionalização. A reforma Jaime Moniz (Decreto de 22 de dezembro, 1894; Decreto de 14 de setembro, 1895; Decreto de 14 de agosto, 1895; Carta de lei de 28 de maio, 1896) deu corpo ao que se pode chamar a refundação do ensino liceal, consolidando-o como processo modernizador, etapa que se estenderia até à década de trinta do século XX (NÓVOA; BARROSO; Ó, 2003). Paradoxalmente, ou talvez não, foram os governos da Ditadura e do Estado Novo que reuniram condições, materiais e organizacionais, para concretizarem, em toda a rede pública de liceus portugueses, as conceções (e resoluções) normativas e disciplinares relacionadas com o processo de socialização dos alunos que desde o século XIX ecoavam na arena educativa (Ó, 2009) e viriam a constituir um tempo de inequívoca expansão dos liceus, particularmente a partir da reforma de Pires de Lima, em 1947.

A população discente dos liceus conheceu um crescimento significativo após a reforma Jaime Moniz e fixou-se entre os 10 a 12 mil alunos, por ano, durante a Primeira República. Nos anos imediatos ao 28 de maio, apesar das oscilações, atingiram-se os 15 mil alunos e, nos subsequentes, o número de alunos a frequentar o ensino liceal não parou de crescer até 1934-1935, ano letivo em que se fixou em 20.698, representando um crescimento da ordem dos $64 \%$ em relação à $1^{\text {a }}$ República. A partir dessa data e até os primeiros anos letivos dos anos 40, mais do que estagnação, o número de alunos a frequentar os liceus conheceu uma quebra que chegou a ser de cerca de $25 \%$, mais ou menos cinco mil alunos. Quebra, em larga medida, desejada e provocada pelo legislador, como teremos oportunidade de sublinhar. Só em 1946-1947 as matrículas superariam os 20 milhares, valor ultrapassado em 1950-1951, com 21.692 alunos no ensino liceal. Daí em diante, retomou-se a expansão regular da frequência, crescendo cerca de $114 \%$ numa década e atingindo os $123 \mathrm{mil}$ alunos em 1973-1974 (NÓVOA; BARROSO; Ó, 2003, p. 28-29).

De finais de oitocentos e ao longo do século XX, o Estado tende a assumir o controlo da educação das crianças e jovens, sobrepondo-se ao papel das famílias e da Igreja nesse campo, através da estatização do ensino. A emergência do Estado educador compaginou-se com o desenvolvimento de políticas no âmbito da formação e da carreira docente, potencializadoras da profissionalização dos 
professores. Concomitantemente, corporizou-se uma pedagogia dita científica sustentada nas disciplinas das ciências sociais e humanas, de vincado cariz sociológico e psicológico. O novo modelo pedagógico centrou-se na autonomia dos educandos e articulou a intervenção de diferentes especialistas (reitores, professores, médicos e enfermeiros) sobre o adolescente transformando-o em aluno, atuando sobre a sua conduta e a cultura de si (Ó, 2009; NÓVOA, 2002). O dispositivo curricular liceal, cujas componentes ainda hoje estão largamente presentes, contribuiu para a construção social de identidades adolescentes e consolidou uma gramática escolar que enforma a nossa conceção de ensino: o agrupar dos alunos em classes graduadas, mais ou menos homogêneas, no campo do saber, bem como no comportamento; professores especialistas de uma disciplina articulados ao nível de classe em prol da aquisição de conhecimentos das diferentes disciplinas do plano de estudos; pedagogia centrada na sala de aula enquanto espaço específico para o trabalho escolar; horários escolares rígidos patenteando um controlo social do tempo e uma hierarquização dos saberes de acordo com as normas da higiene; saberes disciplinarizados, preocupação primeira do ensino e da pedagogia (NÓVOA; BARROSO; Ó, 2003). O modelo tornou-se hegemónico transformando-se no único sistema concebível (TYACK; TOBIN, 1994) e perpetuando-se no tempo, de certo modo impenetrável a uma reestruturação (TYACK; TOBIN, 1994).

É neste quadro de inexorável afirmação do dispositivo curricular liceal, dando corpo, forma e exequibilidade ao programa da modernidade, que se inserem as opções de política educativa para os liceus, adotadas entre as décadas de trinta e cinquenta do século passado, que nos propomos analisar e discutir. Finalidades, o processo de socialização de adolescentes, a transmissão de um cabedal cultural e a preparação para a vida social, bem como para os estudos superiores, conheceram alguma constância. Na verdade, o que realmente se encontrou em jogo não foi o ensino liceal no seu cerne, mas antes a operacionalização e a tradução dessas finalidades. Na década de trinta, o Estado Novo ao demarcar-se de preocupações como o prolongamento de escolaridade e as teses da escola única, recolocou o problema da identidade do ensino do liceu despoletando um debate em torno da sua especificidade, com o complexo debate de ideias a incidir sobre três eixos, os objetivos do ensino liceal, a organização curricular e a democratização (NÓVOA, 1992).

A montante da política educativa que o Estado Novo encetou no segundo lustro da década de trinta encontrava-se a tomada de posse de Antônio de Oliveira Salazar como Ministro das Finanças, em 1928, e a publicação da reforma orçamental que previa a redução das despesas em todos os ministérios de modo a equilibrar, em cada um deles, o orçamento de receitas e despesas ordinárias. Para o efeito foi criada uma comissão de reforma orçamental, por ministério, 
cujos presidentes, no seu conjunto, constituíram a junta de reforma orçamental. Genericamente, cada comissão de reforma tinha a incumbência de preparar as reduções com pessoal, automóveis, telefones, objetos de expediente e outros para equilibrar orçamento de receitas e despesas ordinárias, indicar instituições, repartições e serviços que deviam ser extintos, formular reduções nos restantes quadros e propor outras reduções de despesa (Decreto n. ${ }^{\circ}$ 15.645, 1928). A excessiva preocupação com as finanças e o equilíbrio orçamental, apesar da censura, não passou sem observações críticas dos atores educativos. Publicado no Comércio do Porto e integralmente transcrito na revista Labor, Agostinho de Campos, professor liceal e universitário aposentado, recordava palavras que proferira numa conferência vinte e seis anos antes, em que teria sustentado que as mesmas causas produziam sempre os mesmos efeitos, salientando que "endireitadas amanhã as finanças públicas, a mesma gente, formada nas mesmas escolas, as entortaria de novo fatalmente, pelos mesmos processos" (CAMPOS, 1929).

A comissão de reforma do Ministério da Instrução Pública, nomeada por portaria de 21 de maio de 1928, nos seus relatórios começava por considerar o parque escolar insuficiente para "dar educação secundária àquela parte da população que a ela tem direito”. Os liceus disponíveis davam, no entanto, resposta à procura de educação. Contudo, as assimetrias na procura social de ensino liceal, nomeadamente entre os espaços rural e urbano, reclamavam por uma racionalização. A comissão optou por propor a delimitação, para cada liceu, de "uma zona geográfica de influência pedagógica, em harmonia com a capacidade das suas instalações, valor do material didático, potência do seu quadro efectivo, situação topográfica, condições mesológicas especiais, facilidades de transporte e comunicações" (PORTUGAL. Relatórios da Comissão de Reforma Orçamental, 1929, p. 50-51). Esforço que permitiria reduzir os custos com pessoal docente, diminuindo o número de professores provisórios, e orientar uma parte dos alunos para as escolas técnicas ou para o ensino privado (NÓVOA; BARROSO; Ó, 2003). Se a proposta de reorientação de alunos e o incentivo das escolas técnicas foi considerada em sede de relatórios da comissão, terá sido a do reforço do ensino privado que mereceu melhor atenção e a que se revelaria mais eficaz. Neste domínio considerava a comissão do orçamento do MIP que a política pedagógica, no âmbito da educação secundária geral, tinha sido mal orientada. Assinalava a falta de proteção e estímulo à iniciativa privada resultando daí um número insignificante de colégios de ensino secundário. Ao arrepio da situação internacional, escrevia-se, em Portugal o ensino liceal estava quase exclusivamente a cargo do Estado. Em Portugal apenas $28 \%$ da frequência dependia do ensino secundário particular. Comparava-se com Espanha, assinalando-se que "os colégios e os professores livres" tinham a seu cargo $70 \%$ da população que frequentava o ensino secundário. $\mathrm{O}$ recurso à legislação sobre os exames, 
mobilizados como instrumento de regulação, revelar-se-ia eficaz, resultando na efetiva transferência de grande número de alunos para os colégios. Doravante o crescimento da população a frequentar o ensino liceal far-se-ia a expensas dos colégios (NÓVOA; BARROSO; Ó, 2003).

A comissão de reforma avançava com uma outra medida de contenção que faria o seu caminho, tratava-se da "selecção de candidatos pelo emprego de tests adequados", os exames de admissão. Acrescentava a comissão, na sua apreciação, que cerca de $30 \%$ dos alunos matriculados na $1^{\text {a }}$ classe (dos liceus) eram eliminados no decurso do ano letivo pelo que seria legítimo concluir que só haveria "vantagens em expurgar" os liceus destes alunos, logo "no começo do ano" (Relatórios da Comissão de Reforma Orçamental, 1929). A seleção científica dos alunos ganhou forma na mudança de lustro da década de trinta com a implementação dos "exames de entrada", percebidos como uma das aplicações dos métodos psicotécnicos e como o meio eficaz para melhorar os resultados ao longo do curso liceal. Legitimados pela investigação científica de cariz psicopedagógico, coube a Oliveira Guimarães, psicólogo da direção do Instituto de Orientação Profissional, a sua defesa. Na verdade, como já anteriormente foi sublinhado (NÓVOA; BARROSO; Ó, 2003), as políticas educativas tendem a legitimar-se com argumentos científicos.

Numa outra escala, a política educativa, até perto do final do primeiro lustro dos anos trinta, caracterizou-se por uma certa cadência na mudança de responsáveis ministeriais e pelo recurso constante ao ato legislativo, factos que não podem ter deixado de afetar o quotidiano dos liceus. Logo em outubro de 1926, com Ricardo Jorge (1858-1939) como titular do ministério, o Estatuto de Instrução Secundária (PORTUGAL, Decreto $\left.\mathrm{n}^{0} 12.425,1926\right)$ alterou a estrutura antecedente. Reduziu a escolaridade liceal de 7 para 6 anos. O curso geral continuou com a mesma duração e permaneceu dividido em dois ciclos mas, ao invés do que se encontrava em vigor, agora era o $1^{\circ}$ ciclo que tinha a duração de três anos e o $2^{\circ}$ com apenas dois. O curso complementar, reduzido a um ano manteve os dois percursos, no entanto, em letras, o Francês substituiu a Matemática, e no de ciências, desdobravam-se as Ciências Geológicas e retiravam-se o Português, o Inglês e o Alemão. A redução marcava, em diferentes níveis, a preocupação do legislador. Um ano mais tarde, com Alfredo de Magalhães (1870-1958) como titular do MIP, o curso complementar dos liceus, voltava a ter a duração de dois anos (PORTUGAL, Decreto $\left.n^{\circ} 13056,1927\right)$. A situação não se terá alterado de forma substantiva mesmo depois de António de Oliveira Salazar se ter alcandorado a ministro das finanças, de tal sorte que em 1929 é denunciada a ausência de um plano e de uma direção para a educação, apontando-lhe, como variável constante, as tomadas de decisão contraditórias e a consequente descontinuidade da política educativa. Para além da ausência de 
rumo, a frequente mudança de responsável político pelo ministério da instrução pública e a sua postura, eram apontadas como causas maiores para a situação da educação em Portugal. Agostinho de Campos expressava-o de forma eloquente, estabelecendo o contraponto com a situação vivida no ministério das finanças:

Enquanto um só ministro das finanças segue, sempre igual e fiel a si mesmo, um plano traçado para equilibrar o orçamento e reabilitar o crédito público, não se traçou nenhum plano para transformar em viveiros de trabalhadores da nação as fábricas de parasitas do Estado; e seis, oito, dez ministros da instrução sucedem-se uns aos outros, sem leme e sem rumo, diferentes, dispares e disparatados em tudo, menos em dois pontos constantes: na invariável convicção que cada um [se] aplica a revogar o que fez o anterior; e na modéstia com que todos se resignam a ser arrastados pela traquitana desengonçadíssima de que se intitulam ou se julgam condutores.

[...] Cada ministro que chega, como não pode fazer nada, legisla, coisa fácil, mas terrível, porque é bem evidente que, com tanta legislação, não pode haver lei (CAMPOS, 1929, p. 413).

Um ano mais tarde, já durante uma das passagens de Gustavo Cordeiro Ramos pela pasta da Instrução Pública, os dois ciclos do curso geral passavam a ter, novamente, a duração de dois anos, o primeiro, e três o seguinte (PORTUGAL, Decreto 18.779, 1930). No início da década de trinta coincidente com a(s) estadia(s) de Cordeiro Ramos no ministério, assistiu-se a uma afirmação de controlo sobre pessoas e ideias. Facto visível no quadro disciplinar sobre os atores, os professores, ainda que neste caso particular se limitasse a reafirmar o quadro legal estabelecido por Ginestal Machado (PORTUGAL, Decreto ${ }^{\circ}$ $7.558,1921$ ), e os alunos (PORTUGAL, Decreto $\mathrm{n}^{\circ} 21.160$, de 1 de abril, 1932). No campo das ideias, as normas definidas, nomeadamente para a feitura dos compêndios de História de Portugal, foram clarificadas de forma imperativa (PORTUGAL, Decreto $\mathrm{n}^{\circ}$ 19.605, de 15 de abril, 1931) (PORTUGAL, Decreto $\mathrm{n}^{\circ} 21.103$, de 7 de abril, 1932). Em dezembro de 1931, através do decreto 20.741 (1932), Ramos procurou concatenar num único diploma a legislação dispersa, promulgando um Estatuto do Ensino Secundário, onde se destacava o facto de se considerar indiscutível que o regime de classe era aquele que melhor se prestava à efetivação do ensino secundário. Seria necessário esperar pelo início da segunda metade da década de trinta, pela definitiva clarificação política e pela progressiva institucionalização do Estado Novo, para se assistir à ulterior transferência da legitimidade política para o campo educativo e a consequente 
consolidação de um rumo para a educação nacional, em geral, e para o ensino secundário, em particular.

Considerando o que vimos discorrendo, o nosso propósito foi centrar a reflexão nos objetivos definidos para o ensino liceal e na sua organização curricular. Nesta perscrutamos a controvérsia em torno do regime de classe e do regime de disciplinas. Debate de ideias recuperado na década de 30 e só definitivamente resolvido com a reforma de Pires de Lima (1947). Constatamos a discussão e as sucessivas tomadas de decisão a propósito da duração e estruturação dos ciclos de estudos. Articulado com os objetivos propostos para o ensino liceal adquiriu alguma relevância a problemática das disciplinas que deveriam integrar, ou não, o plano de estudos bem como a justificação das opções adotadas. Como fontes socorremo-nos da legislação que sustentou as alterações nos planos curricular e disciplinar, dos diários da Assembleia Nacional e dos pareceres da Câmara Corporativa aí publicados, campo votado a dissecar e discutir as propostas de diplomas legais submetidos pelo governo. Mobilizamos, ainda, textos publicados na imprensa de educação e ensino, onde, dentro do quadro político e constitucional da ditadura, era possível dirimir ideias sobre os temas em apreço.

\section{A criação do Ministério de Educação Nacional e a reforma do ensino liceal de 1936}

1936 (PORTUGAL, Decreto-lei no 27.084) constitui a data da primeira reforma marcante, do ensino liceal em Portugal. Nesta época encontrava-se à frente do ministério sobre os assuntos do ensino António Faria Carneiro Pacheco (1887-1957), que corporizou, provavelmente como mais nenhum outro ministro, as ideias de afirmação do salazarismo. Enunciando já a sua ideia com a institucionalização do Ministério da Educação Nacional (MEN) (PORTUGAL, Lei 1941, 1936), a sua ação constituiu a melhor expressão da transferência da legitimidade política do novo regime para a arena da educação. O contributo ideológico da educação para a formação social portuguesa marcou indelevelmente a reforma do ensino secundário, como o destacava Marques de Carvalho, considerando que a "formação integral dos portugueses de amanhã" seria, com a criação do MEN, "nacionalista e cristã" colocando a juventude "ao abrigo dos funestos estragos dos ventos de Moscovo" (PORTUGAL, Diário das Sessões da Assembleia Nacional, n. ${ }^{\circ}$ 74, 1936, p. 417).

O legislador partia de um reduzido número de pressupostos que sustentavam as tomadas de decisão na reestruturação do ensino liceal. Considerando-se 
consciente que muitos dos alunos entravam na vida ativa com a preparação cultural que lhes era dada nos liceus, reconhecia ainda que esse facto conferia uma significativa autonomia à sua estrutura. Deste raciocínio derivava o entendimento que a sua oferta educativa teria de constituir "uma acção formativa completa", traduzindo-se num "estímulo da faculdade de observação" e num certo grau de erudição e de sistematização. Numa lógica consonante, o ensino liceal integrava-se, agora, na missão educativa da família e do Estado, no sentido de promover um "desenvolvimento harmónico da personalidade moral, intelectual e física dos portugueses", visando dotá-los de uma "cultura geral útil para a vida", no respeito pelos preceitos constitucionais. Desta perceção se extraíram consequências para a organização e objetivos dos ciclos, as disciplinas e os conteúdos nelas prescritos e para o regime de frequência (PORTUGAL, Decreto-lei $n^{\circ} 27.084,1936$ ).

A estrutura do ensino liceal tinha, desde logo, que espelhar o "desenvolvimento harmónico" dos portugueses, ora a divisão em ciclos, geral e complementar, era considerada artificial, isto é, "pedagogicamente irreal", não tendo, por isso, correspondência no desenvolvimento do adolescente. Era, pela razão aduzida, uma forma de organização a abandonar. Por outro lado, se o propósito era, naquele momento, munir a geração vindoira de uma "cultura geral útil para a vida" que sentido teria, para esta leitura das realidades portuguesas, a especialização em dois percursos, ciências e letras? Especialização cuja tradição se considerava que fora prejudicial para "uma grande parte da população escolar, sem que se tenha revelado útil para a restante". A fase terminal do ensino liceal deveria, ao invés, corresponder a "uma síntese filosófica dos conhecimentos adquiridos" (PORTUGAL, Decreto-lei n ${ }^{\circ} 27.084,1936$ ).

A questão do regime de estudos - classe ou disciplinas - mereceu análise mais detalhada. $\mathrm{O}$ legislador, detentor do poder de narrar, definiu à partida a sua leitura da realidade educativa passada. A tradição escolar pecara pela ausência de "correlação das disciplinas na sequência dos estudos" mas produzira sólidas preparações. Ao invés, dizia o legislador, nos últimos cinquenta anos, em nome do princípio da "interpenetração dos conhecimentos como instrumento de formação mental" adotaram-se "rígidas e falsas consequências da articulação em classes". A situação, segundo o diploma, afetou a avaliação dos alunos que, por um lado, passaram a ser avaliados sob influência do conjunto das disciplinas, acontecendo passarem a uma disciplina, onde não obtiveram aproveitamento, à sombra de outras e, simultaneamente, não obtendo aproveitamento em duas, eram obrigados a nova frequência de seis disciplinas em que obtiveram aproveitamento. No entendimento espelhado no decreto, a segunda situação era tão injusta que "a brandura dos costumes meridionais" teria possibilitado a passagem de alunos sem aproveitamento em duas disciplinas. Esta realidade, compaginada 
com o excesso de disciplinas e o peso dos programas, por vezes no debate político da época percebidas como consequência do regime de classe, como ilustra o debate em torno da lei 1.941 (1936) e foi denunciado em plena Assembleia Nacional (PORTUGAL, Diário das Sessões da Assembleia Nacional, $\mathrm{n}^{\circ}$ 76, 1936), teria resultado, segundo o diploma, na "lastimável impreparação" com que os alunos se apresentavam nos cursos superiores (PORTUGAL, Decreto-lei $\left.\mathrm{n}^{\mathrm{o}} 27.084,1936\right)$.

Era, norteado por estes pressupostos constituídos em leitura da realidade, que Carneiro Pacheco se propunha construir "uma nova experiência pedagógica". O ensino liceal era organizado em três ciclos sucessivos - o último, em dois semestres -, de acordo com a adequação dos métodos ao desenvolvimento psicofisiológico dos alunos e as disciplinas arrumadas por afinidades e de modo sequencial de acordo com o que melhor servisse a "acção formativa do ensino".

Em nome dos "direitos da saúde física" e dos "limites da capacidade intelectual" reduzia-se substancialmente o número de disciplinas em cada ano, expurgavam-se os programas das "inutilidades" e se permitia a frequência parcial (PORTUGAL, Decreto-lei $n^{\circ} 27.084,1936$ ). O legislador alinhava com o posicionamento assumido por diferentes deputados na Assembleia Nacional aquando da discussão da lei de restruturação do Ministério da Instrução Pública (PORTUGAL, Lei 1.941, 1936). A “congestão" dos programas das disciplinas fora então denunciada, sublinhando-se a necessidade de serem "descongestionados, para que as lições" pudessem "ser bem assimiladas" e para que não se viesse a "perder a personalidade do aluno!". Simultaneamente, a aglomeração de matérias ou o caráter enciclopédico do plano de estudos era tido como responsável por "fazer de todo o aluno um disperso" obrigado a "conhecer superficialmente tudo" e não permitindo "penetrar qualquer cousa a fundo" (PORTUGAL, Diário das Sessões da Assembleia Nacional, $\mathrm{n}^{\circ}$ 74, 1936). O deputado Querubim Guimarãis chega mesmo, durante a sua intervenção, a citar uma passagem de Jules Payot (PAYOT, 1935), que considerava interessante por constituir uma denúncia do enciclopedismo mas também pelo seu "relêvo literário":

Caminha! Caminha! Novo judeu errante, hás-de-andar sem parar, hás-de atravessar as matemáticas, a física, a química, a zoologia, a botânica, a geologia, a história de todos os povos, a geografia das cinco partes do mundo, duas línguas vivas, muitas literaturas, a psicologia, a lógica, a moral, a metafísica, a história dos sistemas...

Caminha! Caminha para a mediocridade e leva do liceu ou do colégio o hábito de tudo estudar superficialmente, de tudo julgar pela aparência (PORTUGAL, Diário das Sessões da Assembleia Nacional, nº 76, 1936, p. 421). 
Doravante, os alunos seriam avaliados pelo esforço desenvolvido em cada disciplina, separadamente, e poderiam frequentar disciplinas do ano seguinte com estoutras em que não o alcançaram. Para o legislador um pretenso regime de classe dava lugar a um outro, por disciplinas e coordenado.

O ensino, em cada ciclo, seria ministrado por disciplinas, em aulas dentro do mesmo ano, ou por sessões que poderiam abranger alunos de ciclos ou anos diferentes. Na perspetiva de Riba Leça a orgânica adotada rompia com preconceitos e mostrava-se "mais atenta às realidades passadas e presentes". A divisão em três ciclos compaginava uma sucessão de métodos com a "evolução da personalidade do aluno" e arrumava "as disciplinas pelos diversos anos de cada ciclo, segundo as suas afinidades" e na sequência que melhor se ajustava “à acção formativa do ensino" (LEÇA, 1936, p. 433-434).

$\mathrm{O} 1^{\circ}$ ciclo, com a duração de três anos $\left(1^{\circ}, 2^{\circ}\right.$ e $3^{\circ}$ ano), era composto por cinco disciplinas e teria um ensino prático e descritivo, tendo como objetivos despertar a capacidade de observação e definir a tendência do espírito de cada aluno (PORTUGAL, Decreto-lei $\mathrm{n}^{\circ}$ 27.084, 1936). Acresciam as sessões de Educação moral e cívica, Educação física e Canto coral que, com modificações pontuais, se mantinham nos ciclos seguintes.

1 - Plano de estudos do 10 Ciclo do Ensino Liceal (1936)

\begin{tabular}{l|c|c|c}
\hline \multirow{2}{*}{ a) Aulas } & 10 ano & 20 ano & 3o ano \\
\cline { 2 - 4 } Português & 5 & & \\
Francês & 5 & 5 & 5 \\
Ciências geográfico-naturais & 3 & 3 & 5 \\
Matemática & 3 & 3 & 3 \\
Desenho e trabalhos manuais & 3 & 3 & 3 \\
\cline { 2 - 4 } & 19 & 19 & 19 \\
\cline { 2 - 4 } b) Sessões & & & \\
Educação moral e cívica & 1 & 1 & 1 \\
Educação física & 2 & 2 & 2 \\
Canto coral & 2 & 2 & 2 \\
\cline { 2 - 4 } & 5 & 5 & 5 \\
\hline
\end{tabular}

Fonte: PORTUGAL, Decreto-lei n.o 27:084, 1936.

No $2^{\circ}$ ciclo $\left(4^{\circ}, 5^{\circ}\right.$ e $6^{\circ}$ ano $)$ que se destinava a dotar os alunos de uma cultura geral, pretendia-se que o ensino fosse "teórico e experimental" (PORTUGAL, Decreto-lei $\left.n^{\circ} 27.084,1936\right)$, mantendo-se o número de cinco disciplinas anuais e ainda que estas variassem, a carga de 19 horas semanais manteve-se intacta.

A bifurcação, em ciências e letras, obedecia, para certos autores naquela época, a uma orientação pedagógica adotada no ensino superior por força da especialização dos ramos do saber, fórmula adequada ao seu "progresso especu- 
2 - Plano de estudos do 20 Ciclo do Ensino Liceal (1936)

a) Aulas

Português-latim

Alemão ou inglês

História

Ciências geográfico-naturais

Matemática

b) Sessões

Educação moral e cívica Higiene e educação física

Canto coral

\begin{tabular}{|c|c|c} 
40 ano & 5 ano & 6o ano \\
\hline & & \\
6 & 6 & 6 \\
3 & 3 & 3 \\
3 & 3 & 3 \\
4 & 4 & 4 \\
3 & 3 & 3 \\
\hline 19 & 19 & 19 \\
\hline & & \\
1 & 1 & 1 \\
2 & 2 & 2 \\
1 & 1 & 1 \\
\hline 4 & 4 & 4 \\
\hline
\end{tabular}

Fonte: PORTUGAL, Decreto-lei n.․27:084, 1936.

lativo e prático". A sua introdução prematura produzia especialistas em miniatura que revelavam "incapacidade expositiva, discursiva ou crítica" e, do ponto de vista moral, saíam dos liceus "libertinos e libertários", revelando uma "desconcertante despreocupação das suas responsabilidades íntimas, familiares e sociais" (LEÇA, 1936, p. 431). Em conformidade com esta corrente do pensamento e com a qual Carneiro Pacheco, de algum modo, se identificava, o $3^{\circ}$ ciclo consagrado legalmente confirmava um $7^{\circ}$ ano único para todos os alunos, surgindo dividido em dois semestres, tendo como objetivos sistematizar mentalmente e fornecer uma síntese dos conhecimentos adquiridos (PORTUGAL, Decretolei $\left.\mathrm{n}^{\circ} 27.084,1936\right)$. Para Riba Leça, o novo $7^{\circ}$ ano, ao compaginar a síntese

3 - Plano de estudos do 3을 Ciclo do Ensino Liceal (1936)

\begin{tabular}{|c|c|c|}
\hline \\
\hline Língua e literatura portuguesa & 5 & \\
\hline Latim & & 5 \\
\hline Ciências geográficas & & 4 \\
\hline Ciências biológicas & 4 & \\
\hline Ciências físico-químicas & 3 & 3 \\
\hline Matemática & 2 & 2 \\
\hline Organização Política e Administrativa da Nação & 1 & 1 \\
\hline Filosofia & 4 & 4 \\
\hline & 19 & 19 \\
\hline b) Sessões & & \\
\hline Higiene e educação física & 2 & 2 \\
\hline Canto coral & 1 & 1 \\
\hline & 3 & 3 \\
\hline
\end{tabular}

Fonte: PORTUGAL, Decreto-lei n.ㅇ 27:084, 1936. 
filosófica dos conhecimentos adquiridos com o estudo da estrutura orgânica do Estado e com a formação de uma mentalidade corporativa, penetrava "fundo na criação daquela personalidade forte e consciente" que se pretendia que os alunos tivessem adquirido até à sua entrada na vida social (LEÇA, 1936, p. 432).

Como já anteriormente sublinhamos, o ensino liceal deixava de se perspetivar em função de uma preparação para a prossecução dos estudos mas passava a constituir uma oferta educativa que forneceria uma formação para a vida. A consagração de tal proposta tornava mais premente o contributo ideológico a incorporar no perfil de saída do aluno do ensino liceal. Dimensão visível na preocupação expressa, pelo legislador, com a formação de uma mentalidade corporativa que se compaginou no apelo a valores como a exaltação patriótica e o culto dos heróis, bem como na sua adequação à preparação das alunas para o desempenho da "missão natural da mulher" (PORTUGAL, Decreto-lei ${ }^{0}$ 27.084, 1936).

A inculcação ideológica visava afirmar um conjunto de valores morais veiculados através da exaltação patriótica e do culto dos heróis. Exemplificativas são as sessões culturais bimensais para os alunos do $2^{\circ}$ e $3^{\circ}$ ciclo, que se deveriam traduzir em palestras sobre o império colonial, a arte portuguesa e a educação cívica, ou o ensino do Canto coral, transversal aos sete anos de ensino liceal, onde se deveriam ministrar "noções fundamentais da música e do canto" e se propunha constituir "massas culturais ativas". No $1^{\circ}$ ciclo competia, ao ensino do Canto coral, impregnar os alunos de "preceitos morais e cívicos de um bom português", mobilizando canções educativas e formando o primeiro orfeão. Nos ciclos seguintes visava-se "o culto das glórias de Portugal e a exaltação do sentimento patriótico, tendentes a uma forte e ativa coesão nacional, por meio de cânticos vigorosos", formando-se o segundo orfeão (PORTUGAL, Decreto-lei $\left.\mathrm{n}^{\mathrm{o}} 27.084,1936\right)$. No âmbito do Canto Coral, o legislador encerrava com uma orientação lapidar:

d) O hino e os cânticos nacionais, oficialmente harmonizados, serão motivo de execuções frequentes por todos os alunos, e estarão sempre prontos, tanto para as festas escolares como para as manifestações do sentimento pátrio, em conjugação com a Mocidade Portuguesa (PORTUGAL, Decreto-lei nº 27.084, 1936, p. 1238).

O Canto Coral era visto como um momento coletivo de exaltação nacionalista contribuindo para o reconhecimento e a identificação de cada um com o todo e com os superiores interesses da Nação. Como sustentou o deputado à 
Assembleia Nacional João Amaral, pelo Canto Coral perpassavam as noções de ordem e de disciplina traduzindo "um forte sentido anti-individualista". No momento em que alguém não respeitasse "as leis do conjunto" produziria, invariavelmente, a desordem, ou seja, "a desarmonia do conjunto" (PORTUGAL, Diário das Sessões da Assembleia Nacional, n 75, 1936, p. 435).

No âmbito dos dois primeiros ciclos, a disciplina de Educação Moral e Cívica, de acordo com o diploma legal, deveria ser objeto de um ensino intuitivo, tendo por base "observações acomodadas ao desenvolvimento gradual da receptividade do aluno". Pretendia-se transmitir aos alunos a "verdadeira vida cristã" como tendo um caráter integral e abrangente de "todas as manifestações da vida humana" (PORTUGAL, Decreto-lei n ${ }^{\circ} 27.084,1936$ ). Em texto publicado na Brotéria, assinalavam-se as transformações introduzidas na disciplina, reconhecia-se a distância para um passado próximo e exaltava-se o facto de "a pessoa divina de Jesus" e o "estado do mundo na época do seu aparecimento" terem passado a constituir dados "necessários para a educação da juventude". $\mathrm{O}$ autor sublinhava que a disciplina fora despida, sem reservas, da "atmosfera asfixiante das incongruências e equívocos do laicismo agnóstico ou francamente ateu, pelo ambiente puro e leve da moral cristã". Numa breve análise ao programa assinalava-se nos conteúdos "a instrução sobre o facto religioso, cristão e católico" articulada com a preocupação de dotar os alunos de "uma personalidade forte de responsabilidade e de justiça" (LEÇA, 1936, p. 437) que acolhesse "um desenvolvimento equilibrado dos espíritos, nas vicissitudes da crise intelectual e moral que os esperam na vida" (PORTUGAL, Decreto-lei ${ }^{\circ}$ 27.084, 1936). Concretizava-se uma perspetiva educativa que consubstanciava uma orientação religiosa do sistema de ensino em detrimento da dimensão cívica (NÓVOA, 1992).

O papel da Educação Moral e Cívica enquanto espaço de educação moral e ética, cristã e católica, foi também compreendido pelo seu caráter instrumental de controlo individual e social. É nesta perspetiva que o deputado da Assembleia Nacional Correia Pinto sublinhava a importância da educação religiosa, com a curiosidade de, na sua intervenção, esclarecer que até Benito Mussolini conservara a educação religiosa precisamente por, segundo o deputado, "a mocidade educada religiosamente" nunca poderia "ser perigosa nem para si, nem para os outros", nem para o seu país (PORTUGAL, Diário das Sessões da Assembleia Nacional, $\mathrm{n}^{\mathrm{o}} 75,1936$, p. 437).

O contributo ideológico da educação emergia, ainda de forma direta, na inclusão da disciplina de Organização Política e Administrativa da Nação no plano de estudos do terceiro ciclo, visando o conhecimento da estrutura orgânica do Estado, bem como a formação da mentalidade corporativa, ou na designação de cada liceu pelo nome de "um grande vulto da história pátria". À 
disciplina era atribuído um caráter elementar e descritivo e o programa, depois de noções fundamentais, passava em revista os elementos estruturais da nação, a organização política - os órgãos de soberania - e administrativa e a organização corporativa. Com o ensino da organização corporativa o legislador pretendia integrar "os alunos na atmosfera ideológica" em que se desenvolvia "a acção do Estado". Recomendava-se que se acentuasse a originalidade portuguesa em face de experiências estrangeiras e determinava-se que o professor, sempre que viesse a propósito, deveria "estimular o ardor cívico do estudante, o culto pela idea da Pátria, o respeito pela tradição, o amor da família e a crença nos benefícios da associação" (PORTUGAL, Decreto-lei n 27.084, 1936).

Paralelamente ao $3^{\circ}$ ciclo estava previsto o funcionamento, exclusivamente nos liceus femininos, de um curso especial de educação familiar, considerado como uma necessidade premente, num momento em que "tantos males poderão ser evitados pela habilitação das mães e pelo prestígio do lar" (PORTUGAL, Decreto-lei $\left.n^{\circ} 27.084,1936\right)$. Constituía, de alguma maneira, uma solução adequada para aqueles que consideravam que a ausência de formação para futuras mães e donas de casa fazia dos liceus "um instrumento de desagregação social" (LEÇA, 1936, p. 432). Destinado a alunas com diploma do $2^{\circ}$ ciclo, nas disciplinas comuns ao $3^{\circ}$ ciclo, as alunas que o tivessem concluído seriam

\begin{tabular}{|c|c|c|}
\hline \multirow[b]{3}{*}{ a) Aulas } & \multicolumn{2}{|c|}{70 ano } \\
\hline & 1ㅇs semestre & 20 semestre \\
\hline & & \\
\hline Língua e literatura portuguesa & 5 & \\
\hline Práticas de línguas vivas & 4 & 4 \\
\hline Moral geral, familiar e social & 3 & \\
\hline Métodos de educação familiar & & 2 \\
\hline Economia e arte domésticas & & 2 \\
\hline Noções elementares de economia política e social & & 2 \\
\hline Organização Política e Administrativa da Nação & 1 & 1 \\
\hline Direito usual & & 2 \\
\hline Higiene e puericultura & 1 & 1 \\
\hline Roupa branca, vestidos, transformações & 2 & 2 \\
\hline Chapéus & & 2 \\
\hline Bordados e tapeçarias & 2 & 2 \\
\hline \multirow[t]{2}{*}{ Flores e arte aplicada } & 2 & \\
\hline & 20 & 20 \\
\hline \multicolumn{3}{|l|}{ b) Sessões } \\
\hline Culinária & $\mathrm{n}$ & $\mathrm{n}$ \\
\hline Educação física & 1 & 1 \\
\hline \multirow[t]{2}{*}{ Canto coral } & 1 & 1 \\
\hline & $2+n$ & $2+n$ \\
\hline
\end{tabular}

Fonte: PORTUGAL, Decreto-lei n.ำ27:084, 1936. 
dispensadas da sua frequência. Previa-se que o ensino das matérias privativas do curso, essencialmente práticas, pudesse vir a ser realizado fora do liceu, "em postos de puericultura, lactários, creches, jardins-de-infância e outros serviços sociais", contando-se com a colaboração da Obra das Mães pela Educação Nacional (OMEN) para a instalação e funcionamento do curso (PORTUGAL, Decreto-lei $\left.\mathrm{n}^{\circ} 27.084,1936\right)$.

Globalmente, a marca de modificação espiritual e a carga ideológica perpassam pelos programas das disciplinas, nos diferentes ciclos, como de resto foi à época reconhecido. Dimensões visíveis, por exemplo, no Português, onde para o estudo de Eça de Queiroz e do romance realista, competiria ao professor selecionar leituras de molde a evitar "o escolho de abafar, sob o interesse forte de mórbidas emoções, a disposição para a actividade crítica de análise" (PORTUGAL, Decreto-lei $\mathrm{n}^{\circ}$ 27.084, 1936). De igual modo, os programas de História foram considerados por Riba Leça, "exemplarmente redigidos" (LEÇA, 1936, p. 437) sob o ponto de vista religioso e moral.

No sentido de apoiar o ensino liceal no "desenvolvimento harmónico da personalidade moral, intelectual e física dos Portugueses", o legislador mobiliza a Mocidade Portuguesa, a quem competirá cooperar com as instituições educativas de ensino liceal, oficiais ou particulares, na organização de atividades, obrigatórias para professores e alunos, para o "desenvolvimento da capacidade física, à formação do carácter e à devoção à Pátria, no sentimento da ordem, no gôsto da disciplina e no culto do dever militar" (PORTUGAL, Decreto-lei $\left.n^{\circ} 27.084,1936\right)$. A apreciação da medida por Riba Leça deixa bem vincada a preocupação de inculcação ideológica vertida para o documento:

Esta integração de professores e alunos numa vida nova, de ordem, disciplina e dever, orientada para a consciente efetivação da unidade nacional, tão quebrantada por um século de liberalismo, há-de criar o Portugal verdadeiramente restaurado (LEÇA, 1936, p. 436).

\section{Uma reforma anunciada... (1947)}

As alterações introduzidas com a reforma de 1936 tiveram uma longevidade desigual e, inclusivamente, o alcance terá sido de certo modo limitado já que o Estatuto do Ensino Secundário, datado de 1931, se manteve em vigor (PORTUGAL, Decreto ${ }^{\circ}$ 20.741, 1932). A distinção entre curso geral e curso 
complementar, bem como a diferenciação de percursos nestoutro, sofreria alteração logo no início da década seguinte com a chegada ao ministério de Mário de Figueiredo (1890-1969). Em 1941 reconsagrava-se a existência do curso geral dos liceus, subdividido em dois ciclos de três anos, e do curso complementar de ciências e outro de letras, com a duração de apenas um ano. O ensino liceal fixava-se, assim, nos sete anos de escolaridade (PORTUGAL, Decreto-lei ${ }^{\circ}$ 31.544, 1941).

Efetivamente, a proximidade do segundo lustro da década de quarenta deixa perceber uma vontade de mudar o estado de coisas no ensino liceal, quiçá também influência dos ventos de mudança que, de forma cada vez mais forte e consistente, assolavam o continente europeu. Por portaria, em 1944, chega mesmo a ser nomeada uma Comissão de Reforma do Ensino Liceal (CREL), liderada pelo diretor geral do Ensino Liceal, António Augusto Riley da Motta. A CREL desenvolveu ações no sentido de auscultar as escolas e os reitores. Um inquérito endereçado aos reitores dos liceus, versando a diferenciação de estudos entre rapazes e raparigas e sobre a sensível questão da coeducação, acabaria por conduzir ao afastamento de Riley da Motta (ADÃO; REMÉDIOS, 2008).

A Assembleia Nacional testemunhava precisamente este pulsar. Destaquemos, a título ilustrativo, primeiro, a preocupação com a situação remuneratória e a precariedade laboral nomeadamente dos professores agregados, bem como as desigualdades de condições entre professores efetivos, agregados e auxiliares. $\mathrm{Na}$ sua intervenção, o professor Marques de Carvalho sublinhava que lhe parecia que "as boas condições de trabalho dos agentes de ensino" constituíam condição sine qua non para se encarar "com seriedade qualquer reforma" (PORTUGAL, Diário das Sessões da Assembleia Nacional, $\mathrm{n}^{\mathrm{o}}$ 131, 1945, p. 250). No ano seguinte, o deputado Ernesto Subtil apresentou-se perante a assembleia focalizando a sua atenção na rede escolar do ensino liceal, nos quadros de professores, propondo o seu alargamento, e avançando com uma $3^{\text {a }}$ secção, pedagógica, ao nível do plano de estudos do $3^{\circ}$ ciclo, a frequentar pelos candidatos que se destinassem ao magistério primário (PORTUGAL, Diário das Sessões da Assembleia Nacional, $\mathrm{n}^{\circ} 56,1946$, p. $\left.960-961\right)$.

Um conjunto de outras intervenções, nos meses que antecederam a publicação da reforma do ensino liceal, reclamaram da sua urgência e necessidade de uma reforma geral na educação, integradora dos diferentes setores do sistema educativo. Caso de Couceiro da Costa que, durante a discussão da reforma do ensino técnico, começava por reconhecer a obra do Estado Novo mas sublinhava a necessidade de, no âmbito da educação, acelerar "o ritmo do progresso" e de lhe imprimir "um maior vigor". O deputado lastimava mesmo, nesta sua intervenção, a "demora na revisão" da situação dos ensinos primário, secundário e superior (PORTUGAL, Diário das Sessões da Assembleia Nacional, nº 79, 1947, 
p. 382-384). Esta preocupação com uma reforma global, integrada e coerente para toda a Educação Nacional, emerge também nos discursos de Ribeiro Casaes para quem, em face do "estado em que se encontra a educação nacional" considerava urgente "realizar um plano geral de reforma de educação" ou de Maria Van Zeller que, depois recordar as palavras do Presidente do Conselho em que este afirmava a preocupação do governo em "tudo integrar no plano nacional", destacava que, apesar de ter sido levada a cabo uma reforma parcelar, exemplificando com a do ensino técnico profissional, isso não deveria "prejudicar a 'hora de educação"' cuja expectativa geral, no entender da deputada, era que se iniciasse "por [uma] grande reforma geral de ensino". O relator da Comissão de Educação Nacional, Marques de Carvalho, concordava com a necessidade de o Estado Novo necessitar "de uma obra de envergadura pela educação nacional, em ordem à valorização da juventude que tem de receber [...] o facho olímpico da Revolução", no entanto, sublinhava que, de acordo com os especialistas, o melhor processo seria recorrer a reformas parcelares organizadas de forma articulada e harmonizadas (PORTUGAL, Diário das Sessões da Assembleia Nacional, $\left.\mathrm{n}^{\circ} 82,1947\right)$.

É assim, aparentemente, num ambiente favorável e consciente da necessidade de reformas na educação, que oito meses mais tarde, sem discussão na Assembleia Nacional, surgiram as alterações no ensino liceal. A justificação para a urgência da reforma serve de abertura ao próprio decreto (PORTUGAL, Decreto-lei n $\left.{ }^{\circ} 36.507,1947\right)$, seja pelos "numerosos e fundamentados reparos" à situação vivida no ensino secundário, seja pela necessidade de compaginar o ensino liceal com a reforma e as consequentes transformações introduzidas no ensino técnico. O legislador afirmava a disposição de reformar o ensino no sentido de o colocar em sintonia com a índole e as tradições portuguesas, daí que

5 - Plano de estudos do 10 Ciclo do Ensino Liceal (1947)

\begin{tabular}{l|c|c}
\hline \multirow{2}{*}{ Português } & 10 ano & 20 ano \\
\cline { 2 - 3 } Francês & 5 & 5 \\
Ciências Geográfico-Naturais & 5 & 5 \\
Matemática & 4 & 4 \\
Desenho & 3 & 3 \\
& 3 & 3 \\
\hline Religião e Moral & 20 & 20 \\
\hline Educação Física & 2 & 2 \\
Canto Coral & 2 & 2 \\
Trabalhos Manuais & 2 & 2 \\
\hline
\end{tabular}

Fonte: PORTUGAL, Decreto-lei n. 36:507, 1947 
6 - Plano de estudos do 20 Ciclo do Ensino Liceal (1947)

\begin{tabular}{l|c|c|c}
\hline \multirow{3}{*}{ Português } & 3ㅇao & 4 ㅇ ano & 5o ano \\
\cline { 2 - 4 } Francês & 3 & 3 & 3 \\
Inglês & 2 & 2 & 2 \\
História & 5 & 5 & 5 \\
Geografia & 3 & 3 & 3 \\
Ciências Naturais & 2 & 2 & 2 \\
Ciências Físico-Químicas & 2 & 2 & 2 \\
Matemática & 3 & 3 & 3 \\
Desenho & 3 & 3 & 3 \\
& 1 & 1 & 1 \\
\hline Religião e Moral & 24 & 24 & 24 \\
\hline Educação Física & 1 & 1 & 1 \\
Canto Coral & 2 & 2 & 2 \\
\hline
\end{tabular}

Fonte: PORTUGAL, Decreto-lei n. 36:507, 1947

centrasse a sua atenção nos resultados das experiências que se tinham realizado em Portugal. Após ter traçado uma síntese da história do ensino secundário em Portugal concluía que em todos os sistemas experimentados se considerava que os alunos saíam dos liceus sem a preparação adequada para aceder a um curso superior mas, simultaneamente, se sustentava que estavam sem "o grau de formação do espírito e de cultura geral" necessários para o ingresso numa profissão. Era embasado neste entendimento de desadequação da formação dos alunos, que elencava o que considerava serem as questões essenciais para a tomada de decisões sobre o caminho a trilhar: a questão do regime de ensino, por classes ou disciplinas, o número excessivo de disciplinas e a duração dos estudos.

$\mathrm{Na}$ apreciação do regime a adotar, de classe ou de disciplina, a opção do legislador seria determinada pela finalidade do curso geral. Sendo esta, principalmente, o "desenvolvimento harmónico e gradual das faculdades do aluno" e que mais do que conhecimentos, o curso geral deveria permitir a aquisição de "um certo grau de cultura", só, em seu entender, o regime de classe podia ser reconhecido. Para além deste argumento, entendia-se que o desenvolvimento "normal, gradual e progressivo do espírito das crianças" não era compatível com o regime de disciplina. Aduzia, em reforço da opção adotada, que se era verdade que a multiplicidade de assuntos podia constituir um elemento perturbador, a variedade moderada poderia ser benéfica. Na sequência deste argumento, sublinhava que o ensino simultâneo de certas disciplinas era vantajoso, ajudando a combater a fadiga.

Em sintonia com o legislador, um texto que compulsamos na imprensa de educação e ensino, cujo autor passava em revista a "nova reforma do ensino 


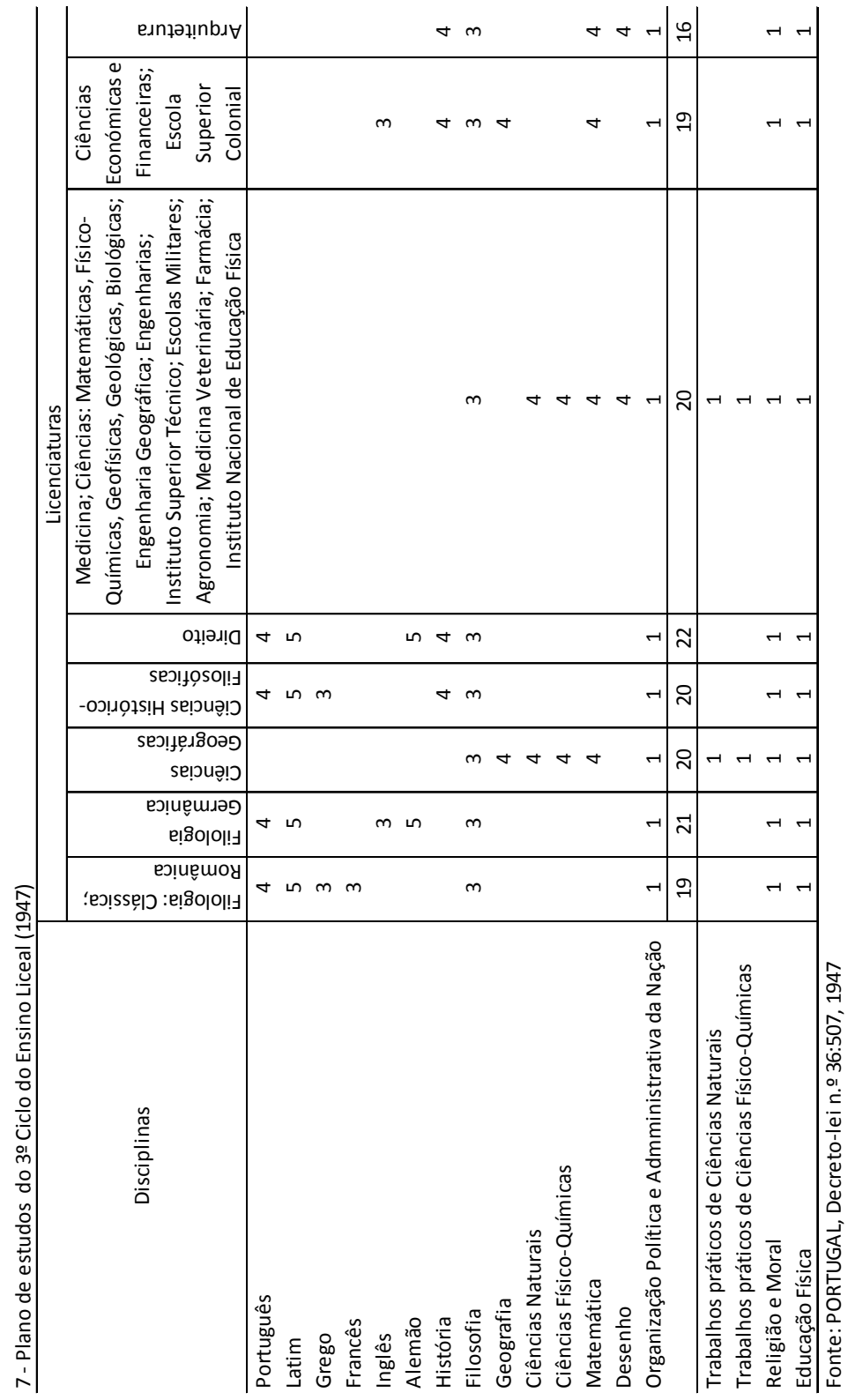


secundário", na discussão dos objetivos do curso geral dos liceus sustentava-se que este curso dispunha o homem para "uma formação imediata para a vida [...] ensinando a saber pensar e sentir, e a exprimir com correcção, em qualquer ramo de actividade" (LEÇA, 1947, p. 313-314). Neste contexto o que se pretendia era, segundo o seu autor, "o desenvolvimento harmónico e gradual das faculdades do aluno" pelo que, ponderando prós e contras, o regime de classe revelava-se o mais eficaz.

Da experiência adquirida era necessário acautelar o exagero na multiplicidade de disciplinas, bem como se deveriam reduzir os programas em todas as matérias não consideradas fundamentais. Nesta perspetiva dever-se-ia tornar mais intenso o ensino das disciplinas que exigissem mais esforço de memória, ao invés daqueloutras que apelassem mais ao "exercício e ginástica da inteligência”. Concluía que se, num ano, num conjunto de sete ou oito disciplinas, o aluno só tivesse de aplicar um esforço particular no estudo de duas ou três, a fadiga não o afetaria e assimilaria o que se propusessem ensinar-lhe. A redução dos programas abrangeria "rubricas que, nada representando para o desenvolvimento intelectual dos alunos, constituíam exercícios inúteis de memória". Nesta perspetiva o legislador previa a redução em disciplinas como a geografia, a história e as ciências naturais, ao passo que na matemática, "pela utilidade manifesta do seu estudo, como exercício intelectual e de aperfeiçoamento do poder de raciocínio", ou nas línguas, cuja matéria não deveria ser esquecida e era de utilidade imediata, a redução seria inaceitável. No curso geral, de acordo com o legislador, deveria ser ensinado o "útil e necessário, como saber, como exercício mental e como elemento de formação" (PORTUGAL, Decreto-lei n ${ }^{\circ}$ 36.507, 1947).

Face a este entendimento, era com naturalidade que surgia, previamente à apresentação das diferentes soluções adotadas para o número excessivo de disciplinas, como que antecipando as tomadas de decisão, o legislador a apontar para a necessidade de se rever o que considerava ser o "velho conceito de humanidades". O seu posicionamento ia, nesta questão, no sentido de acentuar as desigualdades de formação com base no reconhecimento da desigualdade de oportunidades. Na sua leitura, a formação da elite, do escol, impunha-se o conhecimento das humanidades clássicas, contudo, estas não deveriam ter caráter obrigatório para a população em geral, uma vez que à grande massa da população se deveria ministrar "a cultura mais conveniente para que possa dedicar-se ao trabalho de que tem de viver". É com esta ideia norteadora como pano de fundo que aduz um conjunto de outros argumentos para retirar o latim e o alemão do curso geral, remetendo-os para o $3^{\circ}$ ciclo, respetivamente, para os que se fossem matricular nas faculdades de letras e de direito. 
O desejo de desarticulação de um plano de estudos considerado enciclopédico era, aparentemente, consensual, as soluções adotadas é que foram merecedoras de crítica, por parte de certos setores, voltando a colocar na ordem do dia a questão do lugar e do significado das humanidades no currículo do ensino liceal. Escassos três meses após publicação da legislação reformadora, na Assembleia Nacional, a professora de português no ensino secundário, Virgínia Gersão, considerando-se crente nos grandes princípios pedagógicos, declarava-se contra a supressão do latim (PORTUGAL, Diário das Sessões da Assembleia Nacional, $n^{0} 128,1948$, p. 194). Na revista Brotéria, A. Freire (1947), depois de elencar os históricos adversários das humanidades, sublinhava que "a crise intelectual e moral das nações [tinha] coincidido, quási sempre, com tremendas brechas abertas nos baluartes da educação clássica". Na perspetiva de Freire, os estudos humanísticos constituíam o melhor plano de estudos para o "desenvolvimento harmónico e completo das faculdades sensitivas e intelectuais dos jovens", contribuindo para o desenvolvimento da memória, imaginação, inteligência e vontade. Para atingir o que Freire identificava como "um ideal profundamente humano" nenhuma outra disciplina era comparável às humanidades greco-latinas e justificava nestes termos:

Pelo seu caráter sintético, o latim e o grego obrigam a criança a uma distensão permanente e salutar de tôdas as suas faculdades psíquicas, inteligência, memória, imaginação, sensibilidade, logo desde os primeiros rudimentos de gramática e leitura (FREIRE, 1947, p. 200).

E Freire, seguindo a linha de raciocínio, salientava, ainda, que o convívio com os grandes vultos do classicismo greco-romano conferia clareza de pensamento e de forma, precisão, naturalidade e rigor de expressão, bem como equilíbrio de sentimento. Razões bastantes, no seu quadro de representações, para denunciar qualquer ato do legislador no sentido da supressão total ou parcial, como era o caso, do latim.

Outras soluções, adotadas pelo legislador, visando a redução dos programas e o aligeirar da carga de trabalho dos alunos, caso do fim aulas práticas em ciências, foram objeto de crítica, tanto na Assembleia Nacional, em que destacamos Virgínia Gersão (PORTUGAL, Diário das Sessões da Assembleia Nacional, $n^{\circ} 128,1948$, p. 194), como na imprensa de educação e ensino, onde Riba Leça considerou uma má decisão, tanto mais, como destacava, quando o espírito que presidira à organização do curso geral tinha "por fim ministrar a cultura mais conveniente para a satisfação das necessidades comuns da vida 
social" (LEÇA, 1947, p. 318). Igualmente, no sentido de descongestionar os programas do curso geral, o estudo dos Lusíadas passou para o $3^{\circ}$ ciclo, na medida em que só os alunos que se destinavam às licenciaturas de Filologia, Ciências Histórico-Filosóficas e Direito tinham Português, resultava daí que os alunos de ciências realizavam todo o seu percurso escolar liceal sem estudarem a referida obra. Facto que não passou despercebido e foi denunciado por Virgínia Gersão (PORTUGAL, Diário das Sessões da Assembleia Nacional, $n^{\circ}$ 128, 1948, p. 194).

Em termos de estrutura, recusando o aumento para oito anos, ideia que vinha fazendo o seu caminho, uma vez que reconhecia "a necessidade de não retardar o início das carreiras profissionais" e admitia como pouco aconselhável exigir mais um ano de trabalhos escolares aos alunos e às suas famílias, por outro lado, enjeitando a solução brasileira de conferir quatro anos ao curso geral e três ao complementar, na medida em que agravava "o mal de que o ensino liceal tem sofrido", a opção recaiu na manutenção de um curso liceal de sete anos, com o regresso aos cinco anos para o curso geral e dois para o curso complementar, na medida em que, ainda de acordo com o decreto que vimos analisando, existia unanimidade no reconhecimento da "insuficiência de um só ano para os estudos do $3^{\circ}$ ciclo" (PORTUGAL, Decreto-lei n 36.507, 1947).

O curso complementar, $3^{\circ}$ ciclo, com a duração de dois anos e dois percursos, ciências e letras, manteve o regime de frequência por disciplina na medida em que já não se tratava de conferir um grau de cultura geral mas sim de preparar alunos para estudos maiores e, como sublinha o decreto, deveria ser aos "preliminares desses estudos" que os alunos se deveriam dedicar. O $3^{\circ}$ ciclo constituiria, por isso, cursos especializados em função das carreiras a que os alunos se destinassem. O ensino no curso complementar era visto como pré-universitário daí que se pretendesse que fosse intensivo, considerado essencial àqueles que se destinavam a estudos superiores e que careciam "de adquirir sólidos conhecimentos basilares das matérias respetivas". Em consonância com esta perspetiva, o número de disciplinas seria reduzido e atribuía-se uma carga letiva superior às disciplinas a serem lecionadas de novo. Riba Leça, em texto já por nós referenciado, elogiava as opções do MEN para o $3^{\circ}$ ciclo, particularmente, ao nível de letras e direito, pelo latim e por revelar, no seu entendimento, uma preocupação humanística de formação com a inclusão do grego (LEÇA, 1947, p. 316).

De sublinhar a manutenção do peso ideológico no plano de estudos, quiçá acentuada pela adoção de um livro único para todas as disciplinas (PORTUGAL, Decreto $\left.\mathrm{n}^{\mathrm{o}} 36.508,1947\right)$, com a permanência de disciplinas anteriormente referidas, como foi o caso de Canto Coral ou de Organização Política e Administrativa da Nação, acompanhadas agora pela institucionalização do ensino de Religião e Moral, sob alçada da igreja (NÓVOA, 1992, p. 511). 
A solução adotada para o ensino religioso mereceu, naturalmente, o elogio de alguns setores da sociedade. A abrir o seu texto sobre a reforma de 1947, Riba Leça colocava a questão sobre uma apreciação geral da reforma e encontrava-lhe progressos notáveis e retrocessos, porém, sob o ponto de vista religioso considerava-a "digna de encómio", desde logo porque o ensino da religião e moral tinha sido estendido aos três ciclos. Destacava, depois, a nova orientação que se revelava atenta às crenças religiosas dos escolares portugueses, consagrada no Estatuto do Ensino Liceal e que contemplava nas obrigações gerais dos professores e de "quem ensina, o dever de respeitar a consciência católica da Nação e a índole cristã". Ao nível da Religião e Moral como disciplina, embora não tendo exame, Leça assinalava que a frequência das aulas e o comportamento externo nelas eram objeto de "sanções graves" o que constituía um garante de "prestígio e seriedade de ensino". Não deixava, contudo, de lamentar o facto de não se terem consagrado o "cumprimento das obrigações religiosas de preceito" durante o período letivo (LEÇA, 1947, p. 310-311).

Mesmo o próprio Estado Novo parece ter sido obrigado, no domínio ideológico, a compromissos quando confrontado com a própria realidade. A reduzida procura do Curso Especial de Educação Familiar, espelhando pouca aceitação do curso entre as famílias e a procura, pelas jovens, de outros destinos escolares que não a "preparação para mães de família instruídas" (ADÃO; REMÉDIOS, 2008 , p. 54), terá levado os responsáveis políticos a alterar o rumo da política educativa, extinguindo o curso.

A reforma de 1947 publicada cerca de oito dias antes do início do ano letivo de 1947-1948, não foi, como já o referenciamos, objeto de análise e discussão na Assembleia Nacional e os deputados não deixaram de o sublinhar. Como já pudemos testemunhar, o estado de graça foi curto para não dizer inexistente dado que ao fim de uns meses já era objeto de críticas na Assembleia Nacional. Estas confluíam no excesso de trabalho dos alunos com raízes na densidade e extensão dos programas, bem como no caráter enciclopédico dos planos de estudo. Se, logo em abril de 1948, o futuro presidente do conselho de administração da Sociedade Algodoeira de Fomento Colonial, Albano de Magalhães, chamava à atenção da Câmara para a necessidade de ser revista a reforma do ensino liceal, promulgada havia seis meses, já no início do ano, recordemo-lo, Virgínia Gersão, antiga professora agregada da Escola Normal Primária de Lisboa, subira à tribuna para endereçar semelhantes críticas ao estado do ensino secundário após a reforma promovida pelo Ministro da Educação Nacional, Pires de Lima.

O cerne da crítica estava centrado no excessivo tempo, todo o dia, que os alunos passavam nos liceus e o trabalho que tinham de realizar em casa, na resolução de exercícios, na realização de tarefas e no estudo de preparação das aulas do dia seguinte. Para Albano de Magalhães, a nova reforma do ensino 
liceal afastava "os filhos do convívio da família", o que o levou a considerar que a educação liceal tendia "para as pedagogias de tipo totalitário" quando a prioridade da educação deveria ser dada aos pais (PORTUGAL, Diário das Sessões da Assembleia Nacional, nº 155, 1948). Entendia Virgínia Gersão que o tempo que as crianças passavam nos liceus só se justificaria pelo recurso a um ensino ativo que criasse condições para que todas as aprendizagens fossem realizadas nesse período e após o qual os alunos dispusessem de tempo livre. Ora, com turmas de 40 alunos em média, explicava a professora deputada, isso era impraticável, pelo que a sua preocupação primeira era chamar a atenção do governo para o facto de que a criança não podia "fazer esforços intelectuais" quando estava cansada. Qualquer criança cansada, afirmava Virgínia Gersão, aprendia "automaticamente, sem interesse, para esquecer depois" (PORTUGAL, Diário das Sessões da Assembleia Nacional, n 128, 1948). Adotando um posicionamento mais marcadamente ideológico, Albano de Magalhães denunciava perante a Assembleia Nacional a gravidade da situação com a implementação da reforma de 1947, uma vez que, simultaneamente, o MEN procedera ao aumento do número de dias de aulas contra os costumes portugueses e a tradição cristã, encurtando as férias de Natal e da Páscoa e eliminando dos feriados escolares a segunda-feira de Carnaval (PORTUGAL, Diário das Sessões da Assembleia Nacional, n 155, 1948). Virgínia Gersão resumia a situação das crianças em Portugal a um dilema, ou levavam uma vida de "absoluto sacrifício" ou não triunfariam nos estudos liceais (PORTUGAL, Diário das Sessões da Assembleia Nacional, $\mathrm{n}^{\circ} 128,1948$ ).

Existia alguma unanimidade, entre os deputados que afirmaram uma posição crítica, nas explicações avançadas para a sobrecarga de trabalho dos alunos no ensino liceal. A dupla justificação estava no enciclopedismo do plano de estudos e na extensão e profundidade dos programas. Como explanaria o deputado Pinto Barriga, professor catedrático da Universidade Técnica de Lisboa, os jovens liceais eram "pequenos 'Picos de La Mirandola', sobrecarregados de programas, de cadeiras e com anti-higiénica absorção de horas, física e mentalmente" (PORTUGAL, Diário das Sessões da Assembleia Nacional, $\mathrm{n}^{\circ}$ 98, 1951). Na opinião de Albano de Magalhães, a reforma executada por Pires de Lima agravou o problema da "densidade dos programas", particularmente no $2^{\circ}$ ciclo, tendo sido criado, avançava o deputado natural de Resende (Viseu), "um curso demasiadamente sobrecarregado de que se não pode esperar senão um precário aproveitamento" (PORTUGAL, Diário das Sessões da Assembleia Nacional, $\left.n^{\circ} 155,1948\right)$. Finalmente, Pinto Barriga concluía que o ensino secundário oficial tinha bons professores, no entanto, "queimados pelos programas" que constituíam, na forma expressiva do deputado albicastrense, "uma autêntica comida de 'entroncamento' intelectual". Para este deputado todos se queixavam, 
pais, alunos e professores, contudo tudo permanecia na mesma, daí que tenha optado por realizar um pedido, ao Sr. Ministro da Educação Nacional, para pôr cobro à situação que descrevia nestes termos:

V. Ex. ${ }^{a}$ faça desaparecer essa espécie de mercado negro de ensino secundário, provocado pela aglomeração de disciplinas e densidade dos programas, onde abundam e se multiplicam dispendiosos explicadores, reexplicadores e repetidores, despedagogicando todo o ensino secundário, desarticulando o aluno, habituando-o a esse «bicarbonato» na sua digestão intelectual (PORTUGAL, Diário das Sessões da Assembleia Nacional, $\mathrm{n}^{\mathrm{o}} 98,1951$, p. 850).

Duas reformas depois e, a avaliar por diferentes intervenções na Assembleia Nacional, o problema do enciclopedismo do plano de estudos e complexidade e extensão dos programas do ensino liceal continuavam a ser merecedores de discussão e crítica. Não devemos, no entanto, perder de vista outras leituras da realidade do ensino liceal pós reforma de 1947. Riba Leça, por exemplo, preferia ver nela o que considerava serem preocupações políticas e pedagógicas. As políticas compaginavam-se com condescendência com a opinião pública interna com objetivos de política internacional. Neste eixo, apontava o autor, a supressão do latim como disciplina autônoma e a importância dada a línguas vivas, particularmente o inglês que, para Riba Leça, não deveria deixar de ser lida "em razão da orientação atlântica e anglo-saxónica da nossa política internacional". As preocupações pedagógicas colocava o autor na tendência de a reforma tornar o ensino "não só mais eficiente, mas de caráter marcadamente pragmatista e utilitário" (LEÇA, 1947, p. 310).

\section{Conclusão}

O ensino liceal em Portugal atingirá o seu auge no Estado Novo. Curiosamente, um século depois da sua criação e de múltiplas e controvertidas reformas, que passam do século XIX para o XX. A generosidade presente na retórica da criação dos liceus nunca encontrou correspondência social e capacidade política ao longo de todo este tempo. Se nos finais do século XIX, se procurou estabilizar uma organização curricular bem pensada, equilibrada e articulada, que atendia 
ao que melhor se fazia na Europa e se pensava adequado às exigências de uma formação que devia garantir a qualidade dos que deviam ocupar os lugares intermédios e superiores da administração pública e privada, não se conseguiu uma aceitação generalizada, pelo que alguns dos aspetos emblemáticos tivessem sido alvo de discussão e revisão nas décadas seguintes, nomeadamente durante o Estado Novo. É exatamente perante este regime ditatorial e conservador que se coloca a nossa análise sobre os planos de estudo dos liceus, reconhecendo, logo à partida, que os pressupostos ideológicos se articulam com um entendimento sobre o modo como se deve organizar a formação do público liceal. Ao longo das páginas anteriores procurou-se apresentar sinteticamente uma compreensão das ideias e das principais características das reformas que pesaram na organização curricular dos liceus em Portugal durante o Estado Novo, na primeira metade do século XX mas procurando situar a análise historicamente, ou seja, considerando a conjuntura social e política e a evolução dos anteriores planos curriculares dos liceus.

Foram objeto de análise, através da discussão dos diferentes planos de estudos, três questões matriciais no desenvolvimento do liceu em Portugal, como sejam, as disciplinas dos diferentes planos de estudos, a organização e duração dos ciclos e o regime de frequência. A discussão com o caráter enciclopédico do currículo e com a complexidade e extensão dos programas, em face das soluções adotadas, como por exemplo a supressão parcial do latim, recolocou na agenda do debate o papel e o lugar das humanidades no ensino liceal. Como demonstramos, enciclopedismo e densidade de programas constituíram duas vertentes que ilustraram a incapacidade, do próprio Estado Novo, para encontrar soluções consensuais no campo educativo. No âmbito das disciplinas e das atividades circum-escolares fica evidente a dimensão de inculcação ideológica introduzida pelo salazarismo no ensino liceal, nomeadamente, nas disciplinas de História e Geografia, com as disciplinas de Canto Coral e Organização Política e Administrativa da Nação, nas sessões culturais bimensais e no papel atribuído à Mocidade Portuguesa. Neste quadro não foi despiciendo o crescente papel da igreja católica através da disciplina de Educação Moral e Cívica para Religião e Moral, passando a ser lecionada em todos os anos do curso liceal.

Independente mas articulada com a definição de um currículo para o ensino liceal, emergiram as questões em torno da construção de dois percursos no ciclo complementar e as derivadas da organização em ciclos, tendo como pano de fundo a procura de uma correspondência ao desenvolvimento dos adolescentes. Entendimento que variou entre as reformas de 1936 e 1947, como de resto sublinhamos, mas que, na verdade consideramos que ainda hoje está longe de ter esgotado a temática, tanto mais que, no quadro de uma certa leitura da realidade presente, é racionalmente aceitável considerar a atual organização em ciclos, 
nos hoje ensinos básico e secundário, artificial e certas transições com pouca ou nenhuma ligação às etapas de desenvolvimento dos destinatários.

Finalmente, o regime de frequência. A mudança de um regime de disciplinas a outro de classes, foi concomitante com debates e o desenvolvimento organizacional de 1936 para 1947, corporizando duas correntes de opinião no seio do Estado Novo. Problemática que ressurgiu na década de trinta do século passado e com algum grau de complexidade não completamente esclarecido dado que o legislador, em 1936, não assumia um regime de disciplinas tout court, mas definia-o como um regime "por disciplinas e coordenado", coordenação que vem sendo percebida, na literatura, como exclusiva do regime de classes. Certo foi que o regime de classes se impôs, novamente, em 1947 e, desde então, tem prevalecido em Portugal.

\section{REFERÊNCIAS}

ADÃO, Á.; REMÉDIOS, M. J. Memória para a frente, e... o resto é lotaria dos exames. A reforma do ensino liceal em 1947. Revista Lusófona de Educação, Lisboa, n. 12, p. 41-64, 2008.

CAMPOS, A. O mesmo que chiar um carro Labor. Revista bimestral do Liceu de José Estêvão e órgão provisório do professorado liceal, Aveiro, n. 22, p. 412-414, dez. 1929.

FREIRE, A. O entêrro oficial do latim (Sob o signo de Bento Pertunhas). Brotéria, Lisboa, v. XLV, p. 201-208, 1947.

LEÇA, R. As reformas do ensino liceal. Brotéria. Lisboa, v. XXIII, p. 429-438, 1936.

Nova reforma do ensino secundário. Brotéria, Lisboa, v. XLV, p. 310-320, 1947.

NÓVOA, A. A “Educação Nacional”. In: ROSAS, F. (Org.). Portugal e o Estado Novo (1930-1960). Lisboa: Presença, 1992. p. 455-519.

La raison et la responsabilité: Vers une science du gouvernement des âmes. In: HOFSTETTER, R.; SCHNEUWLY, B. (Org.). Science(s) de L'Éducation 19e-20e Siècles - Entre champs profissionels et champs disciplinaires. Berne: Peter Lang, 2002. p. 243-263.

.; BARROSO, J.; Ó, J. R. O Todo Poderoso Império do Meio. In: ; SANTA-CLARA, A. T. (Org.). Liceus de Portugal. Histórias, Arquivos, Memórias. Porto: ASA, 2003. p. 17-73.

Ó, J. R. do. Ensino liceal (1836-1975). Lisboa: Edição da Secretaria-Geral do Ministério da Educação, 2009. 
PAYOT, J. A educação da vontade. Lisboa: Livraria Editora Guimarães e C. a 1935.

PORTUGAL. Decreto de 17 de novembro de 1836. Criação do ensino liceal fixando-se, entre outros aspetos, o conjunto de disciplinas, a rede nacional de liceus e a sua organização. Diário de Governo, Lisboa, 19 nov. 1836.

Decreto de 22 de dezembro de 1894. Aprova a reforma dos serviços de instrução secundária. Diário do Governo, Lisboa, 24 dez. 1894.

Decreto de 14 de agosto de 1895. Aprova o regulamento do ensino secundário. Diário de Governo, Lisboa, 17 ago. 1895.

. Decreto de 14 de setembro de 1895. Aprova programas dos liceus. Diário do Governo, Lisboa, 16 set. 1895.

Carta de lei de 28 de maio. Organiza o ensino secundário. Diário do Governo, Lisboa, 5 jun. 1896.

. Decreto de 29 de agosto de 1905. Reforma do Ensino Secundário. Coleção oficial de legislação portuguesa, Lisboa, v. II, p. 382-390, 1905.

. Decreto $n^{\circ} 7.558$, de 18 de junho de 1921. Aprova o regulamento da instrução secundária. Diário de Governo, Lisboa, 1921.

Decreto $\mathrm{n}^{\mathrm{o}} 12.425$, de 2 de outubro de 1926. Promulga o estatuto do ensino secundário. Diário do Governo, Lisboa, 1926.

Decreto $\mathrm{n}^{\circ} 13.056$, de 22 de janeiro de 1927. Faz várias alterações ao estatuto do ensino secundário. Diário de Governo, Lisboa, 1927.

. Decreto $\mathrm{n}^{\circ} 15.645$, de 14 de maio de 1928. Promulga a reforma orçamental. Diário do Governo, Lisboa, 1928.

. Relatórios da Comissão de Reforma Orçamental. Boletim Oficial do Ministério de Instrução Pública, Lisboa, n. 1-2, p. 45-88, 1929.

. Decreto $\mathrm{n}^{\circ} 18.779$, de 20 de agosto de 1930. Reorganiza os serviços docentes dos liceus. Diário de Governo, Lisboa, 1930.

. Decreto $n^{\circ} 19.605$, de 15 de abril de 1931. Estabelece novas bases para o concurso de livros a adotar nos liceus. Diário do Governo, Lisboa, 16 abr. 1931.

. Decreto $\mathrm{n}^{\circ} 20.741$, de 11 de janeiro de 1932. Promulga o estatuto do ensino secundário. Diário de Governo, Lisboa, 1932.

. Decreto $n^{\circ} 21.103$, de 7 de abril de 1932. Esclarece a latitude da expressão "exactidão das doutrinas", inserta no artigo $13^{\circ}$ do Decreto n. ${ }^{\circ} 19605$, na parte que respeita ao Compêndio de História Pátria para o ensino secundário e técnico. Diário do Governo, Lisboa, 15 abr. 1932.

. Decreto $n^{\circ} 21.160$, de 1 de abril de 1932. Uniformiza e colige num só diploma todas as disposições legais referentes à disciplina académica. Diário do Governo, Lisboa, 25 abr. 1932. 
. Decreto-Lei n ${ }^{\circ} 27.084$, de 14 de outubro de 1936. Promulga a reforma do ensino liceal. Diário do Governo, Lisboa, 1936.

.Diário das Sessões da Assembleia Nacional. Lisboa, n. 74, p. 407-425, 7 fev. 1936.

. Diário das Sessões da Assembleia Nacional. Lisboa, n. 75, p. 427-446, 8 fev. 1936.

. Diário das Sessões da Assembleia Nacional. Lisboa, n. 76, p. 447-464, 11 fev. 1936.

. Lei $\mathrm{n}^{\circ} 1.941$, de 11 de abril de 1936. Estabelece as bases de organização do Ministério da Instrução Pública e altera a sua denominação para Ministério da Educação Nacional. Diário de Governo, Lisboa, 1936.

. Decreto-Lei no 31.544, de 30 de setembro de 1941. Restabelece, no ensino dos liceus, o curso geral e os cursos complementares de letras e ciências; extingue a secção do Carmo do Liceu Passos Manuel; Modifica o regime de frequência do Liceu Pedro Nunes. Diário de Governo, Lisboa, 1941.

. Diário das Sessões da Assembleia Nacional. Lisboa, n. 131, p. 247-250, 1 fev. 1945.

. Diário das Sessões da Assembleia Nacional. Lisboa, n. 56, p. 957-972, 25 mar. 1946.

. Decreto $\mathrm{n}^{\mathrm{o}} 36.508$, de 17 de setembro de 1947. Aprova o estatuto do ensino liceal. Diário do Governo, Lisboa, 1947.

. Decreto-Lei n ${ }^{\circ} 36.507$, de 17 de setembro de 1947. Promulga a reforma do ensino liceal. Diário de Governo, Lisboa, 1947.

. Diário das Sessões da Assembleia Nacional. Lisboa, n. 79, p. 374-394, 25 jan. 1947.

. Diário das Sessões da Assembleia Nacional. Lisboa, n. 82, p. 437-458, 1 fev. 1947. $\overline{\text { jan. } 1948 .}$

Diário das Sessões da Assembleia Nacional. Lisboa, n. 128, p. 191-204, 28

Diário das Sessões da Assembleia Nacional. Lisboa, n. 155, p. 634-657, 30 abr. 1948 .

. Diário das Sessões da Assembleia Nacional. Lisboa, n. 98, p. 843-862, 14 abr. 1951.

TYACK, D.; TOBIN, W. The "Grammar" of Schooling: Why Has It Been So Hard to Change? American Educational Research Journal, v. 31, n. 3, p. 453-479, 1994.

TYACK, D. The one best system: a history of american urban education. Cambridge: Harvard University Press, 1994.

Texto recebido em 20 de dezembro de 2013.

Texto aprovado em 24 de janeiro de 2014. 